\title{
Methyltransferase-Like Protein 13
}

National Cancer Institute

\section{Source}

National Cancer Institute. Methyltransferase-Like Protein 13. NCI Thesaurus. Code C156932.

Methyltransferase-like protein 13 (699 aa, $79 \mathrm{kDa}$ ) is encoded by the human EEF1AKNMT gene. This protein is involved in the inhibition of apoptosis and the methylation of translation elong ation factor 1 a. 